\title{
SIGNIFICANCE OF UGT1A1*28 GENOTYPE IN PATIENTS WITH ADVANCED LIVER INJURY CAUSED BY CHRONIC HEPATITIS C
}

\author{
ZNAČAJ UGT1A1*28 GENOTIPA KOD PACIJENATA SA TEŠKOM FIBROZOM I CIROZOM \\ UZROKOVANOM HRONIČNIM HEPATITISOM C
}

\author{
Jelena Jordovic ${ }^{1}$, Ksenija Bojovic ${ }^{1,2}$, Jasmina Simonovic-Babic 1,2, Vladimir Gasic ${ }^{3}$, Nikola Kotur ${ }^{3}$, \\ Branka Zukic ${ }^{3}$, Marija Vukovic ${ }^{4}$, Sonja Pavlovic ${ }^{3}$, Ivana Lazarevic 2', Ivana Bekic ${ }^{5}$, Natasa Nikolic 1,2, \\ Aleksandar Uroševic 1,2, Nikola Mitrovic 1,2, Dragan Delic 1,2 \\ ${ }^{1}$ Clinic for Infectious and Tropical Diseases, Clinical Centre of Serbia, Belgrade, Serbia \\ ${ }^{2}$ Medical Faculty, University of Belgrade, Belgrade, Serbia \\ 3 Laboratory for Molecular Biomedicine, Institute of Molecular Genetics and Genetic Engineering, \\ University of Belgrade, Belgrade, Serbia \\ ${ }^{4}$ Department for Medical Genetics, University Clinical Centre of the Republic of Srpska, Banja Luka, \\ Bosnia and Hercegovina \\ 5 Institute for Oncology and Radiology of Serbia, Belgrade, Serbia
}

\section{Summary}

Background: Chronic hepatitis $\mathrm{C}(\mathrm{CHC})$ is a significant cause of liver related morbidity and mortality worldwide. The role of genetics in the host response to hepatitis $C$ virus is not elucidated. Genetic variations in UGT1A1 gene are the most common cause of hereditary unconjugated hyperbilirubinemia-Gilbert syndrome. This is the first study investigating the association of UGT1A1 TA repeats promoter genotypes with the degree of liver injury, viremia and biochemical markers in $\mathrm{CHC}$ patients with advanced liver injury and late virological relapse.

Methods: Genetic testing of UGT1A1 TA repeats promoter genotypes was performed in $42 \mathrm{CHC}$ patients with advanced fibrosis and cirrhosis who achieved sustained virological response and 42 healthy blood donors. $\mathrm{CHC}$ patients were evaluated for clinical findings, laboratory tests and imaging.

Results: UGT1A1*28 genotype (7/7 TA repeats) was observed in $23.8 \% \mathrm{CHC}$ patients and $16.7 \%$ healthy controls with no significant difference in genotype frequencies $(p=0.49)$. Pretreatment levels of ferritin and

Address for correspondence:

Jelena Jordovic, MD

Clinic for Infectious and Tropical Diseases,

Clinical Centre of Serbia

Bulevar Oslobođenja 16, 11000 Belgrade

e-mail address: jelenajejelena@yahoo.com

Phone: +381643210398

\section{Kratak sadržaj}

Uvod: Hronični hepatitis C (HHC) je značajan uzročnik morbiditeta i mortaliteta u svetu. Značaj genetskih faktora u patogenezi HHC još uvek nije u potpunosti razjašnjen. Varijacije UGT1A1 gena su najčešći uzrok nasledne nekonjugovane hiperbilirubinemije - Žilberovog sindroma. Ovo je prva studija koja se bavi ispitivanjem učestalosti TA ponavljanja u promotorskoj regiji UGT1A1 gena i analizom povezanosti UGT1A1*28 genotipa sa stepenom fibroze, viremijom i biohemijskim markerima kod pacijenata sa teškim oštećenjem jetre izazvanim HHC i virusološkim relapsom.

Metode: Analizirana su TA ponavljanja u promotorskoj regiji UGT1A1 gena, kod 42 pacijenta sa teškom fibrozom i cirozom izazvanom HHC, koji postigli stabilan virusološki odgovor i 42 ispitanika u kontrolnoj grupi zdravih dobrovoljnih davalaca krvi. Pacijenti sa HHC su dodatno analizirani kliničkim pregledima, laboratorijskim analizama (hematološki, biohemijski i virusološki) i fibroskenom jetre. Rezultati: UGT1A 1*28 genotip (7/7 TA ponavljanja) je bio prisutan kod $23.8 \%$ pacijenata sa HHC i 16,7\% zdravih
List of abbreviations: UGT1A1, uridine diphosphate-glucuronosyl transferase 1A1; GS, Gilbert syndrome; TA repeats, thymine-adenine repeats; CHC, chronic hepatitis C; SVR, sustained virologic responce; HIV, human immunodeficiency virus; PCR HCV RNA, polymerase chain reaction hepatitis C virus ribonucleic acid; DNA, deoxyribonucleic acid; ALT, alanine aminotransferase; AST, aspartate aminotransferase; GGT, gamma-glutamyl transpeptidase; AFP, alpha-fetoprotein; EOT, end of treatment; HCC, hepatocellular carcinoma. 
bilirubin were associated with the presence of UGT $1 A 1 * 28$ genotype, indicating its potential as a predictive marker. However, in our study, there was no correlation of UGT1A1*28 genotype with the degree of fibrosis or viremia. During antiviral treatment, dose reductions and treatment interruptions, as well as treatment success and occurrence of late virological relapse were not related to the presence of UGT1A1*28 genotype in $\mathrm{CHC}$ patients with severe liver injury.

Conclusions: Frequencies of UGT1A1*28 genotype are high in both Serbian $\mathrm{CHC}$ patients and healthy subjects. The presence of UGT1A1*28 genotype was not associated with ribavirin-related adverse effects and had no effect on long term outcome in $\mathrm{CHC}$ patients.

Keywords: Gilbert syndrome, hepatitis C, hyperbilirubinemia, late relapse, UGT1A1

\section{Introduction}

Enzyme uridine diphosphate-glucuronosyl transferase 1A1 (UGT1A1) is responsible for bilirubin conjugation with glucuronic acid, inducing water solubility of bilirubin and allowing urine excretion of the bilirubin-glucuronide conjugates (1). Numerous enzymes from UGT family catalyze glucuronidation of xenobiotics, mutagens, and reactive metabolites, acting as indirect antioxidants. Published data have also demonstrated anti-inflammatory and antioxidant functions of its substrate bilirubin $(2,3)$. The presence of genetic variations in UGT1A1 gene encoding UGT1A1 enzyme cause alteration of the enzyme leading to reduced activity. These genetic variations in UGT1A1 gene are the most common cause of mild hereditary intermittent unconjugated hyperbilirubinemia-Gilbert syndrome (GS) (4). The insertion of thymine-adenine (TA) repeats in the promoter region (wild type consists of 6 TA repeats), reduces gene transcription by $67-82 \%$, with subsequent reduction of enzyme activity by $20-30 \%$ (5). UGT1A1*28 variant allele contains 7 TA repeats, and individuals with GS possess 7/7 homozygous genotype with two UGT1A 1*28 alleles. Although GS is considered a benign condition, new pharmacogenetic discoveries have shown that certain UGT1A1 alleles are responsible for adverse outcomes and higher risks for breast and colorectal cancer due to decreased detoxification of carcinogens. Higher risks for severe drug reactions (irinotecan, nilotinib, pazopanib, belinostat, atazanavir) have been documented in patients with certain homozygous UGT1A1 alleles and reduced enzyme activity (5-10). Pretreatment pharmacogenomic testing can greatly assist in individualizing therapy and might prompt special caution /different treatment options, due to a higher risk of side effects such as jaundice, diarrhea and neutropenia (11). Other UGT1A1 genetic variants were also studied as a possible prognostic markers in chronic hepatitis B infection and predictors of onset of hepatocellular carcinoma in chronic hepatitis C (CHC) (12). ispitanika, ali bez statistički značajne razlike $(p=0,49)$. Nivoi feritina i ukupnog bilirubina su bili u korelaciji sa prisustvom UGT1A1*28 pre primene antivirusne terapije, što sugeriše prediktivnu ulogu ovog genotipa. $U$ ovoj studiji nije bilo korelacije UGT1A1*28 genotipa sa stepenom fibroze i viremijom. Prisustvo UGT1A1*28 genotipa nije uticalo na terapijske prekide i redukcije doze antivirusnih lekova, ishod lečenja niti pojavu kasnog virusološkog relapsa kod pacijenata sa HHC i teškim oštećenjem jetre.

Zaključak: Učestalost UGT1A1*28 genotipa je visoka među srpskim zdravim ispitanicima i pacijentima sa $\mathrm{HHC}$ infekcijom. Ispitivani genotip se ne dovodi u vezu sa neželjenim efektima ribavirina niti ima uticaj na ishod lečenja i dugoročnu prognozu pacijenata sa HHC.

Ključne reči: Žilberov sindrom, hepatitis $C$, hiperbilirubinemija, kasni relaps, UGT1A1

Prevalence of GS varies worldwide, estimated in 5-16\% European blood donors, but as many cases are unsymptomatic and undiagnosed, true prevalence is probably much higher (13). Although considered a mild condition, there is very little data about GS in chronic liver disease, especially in $\mathrm{CHC}$, including interpretation of bilirubin levels in conjunction with other liver-injury markers and clinical features.

Published data concerning the epidemiology of $\mathrm{CHC}$ in Serbian population show that estimated seroprevalence is higher than in most of the developed European countries, approximately $0.19 \%$ and that genotypes $1 \mathrm{~b}$ and $3 \mathrm{a}$ are predominate $(14,15)$. In our country, pegylated interferon and ribavirin have been available since 2003. with high treatment success rates. However we have observed in our clinical practice, supported by published data from foreign authors, that liver-related morbidity and mortality is still high in patients with severe baseline liver damage in spite of achieving sustained virologic responce (SVR) (16-18). This particular group of patients has not been evaluated in our souroundings so far. Due to the fact that along with hepatitits $C$ virus, both genetically determined factors and oxidative stress play an important role in liver fibrosis and $\mathrm{CHC}$ pathogenesis, there is a question of importance of UGT1A1 genetic variants as a possible prognostic and therapeutic markers.

Aim of this study was to analyze UGT1A1 TA repeats promoter genotypes frequency in healthy blood donors and study group of patients with severe liver injury caused by $\mathrm{CHC}$. The second aim was to examine possible association of UGT1A1*28 genotype with the degree of liver fibrosis, viremia and biochemical markers in patients who successfuly underwent combined antiviral treatment. In order to examine a possible predictive relevance of UGT1A $1 * 28$ genotype beyond treatment response and SVR, we particularly examined a group of patients with severe fibrosis and cirrhosis who had detectable viraemia in spite of successful treatment. 


\section{Materials and Methods}

The study was performed at the referral center the Hepatology Department of the Clinic for Infectious and Tropical Diseases, Medical Faculty of Belgrade, Clinical Center of Serbia. It included 84 subjects- study group of 42 patients with $\mathrm{CHC}$ and 42 healthy blood donors as a control group. The study group was a small part of a long-term follow-up study of a cohort of 325 patients with severe baseline liver damage caused by $\mathrm{CHC}$, who received antiviral treatment and/or retreatment with pegylated interferon and ribavirin between 2003. and November 2015. We contacted patients from this large cohort, who had successfully undergone antiviral treatment and achieved SVR, for a reevaluation during March-July 2017, including clinical examination, fibroscan, virology, liver and genomic biomarkers. Among patients who responded, 42 individuals fulfilled inclusion criteria and gave consent for participation. Two patients from this group had been retreated during mentioned time period and achieved SVR after retreatment, so they were also recruited. The baseline pretreatment data obtained from patient files, included demographic and epidemiological data, clinical findings, laboratory tests and liver histology, before commencement of antiviral treatment, and regular clinical examinations every 6 months including laboratory tests (hematological, biochemical and virology), imaging (ultrasonography yearly in all patients and fibroscan) and upper gastrointestinal endoscopy (in patients with cirrhosis). Among 42 patients who were regruited, 9 had previously been tested during follow-up and were already known to have virologicaly relapsed, in spite of achieving SVR.

The inclusion criteria for the study group of patients were: patients with a confirmed $\mathrm{CHC}$ infection by polymerase chain reaction (PCR) and advanced fibrosis or cirrhosis (METAVIR score $>$ F2) who underwent a complete antiviral treatment and achieved SVR and gave consent for participation. The exclusion criteria for study group were: age (subjects younger than 16 or older than 65 years), mild liver damage on liver histology (METAVIR <2), coinfections (hepatitis B, HIV), other liver diseases (Wilson's disease, haemochromatosis, autoimmune hepatitis, primary biliary cirrhosis, baseline decompensated liver cirrhosis and hepatocellular carcinoma), severe comorbidities (decompensated cardiomyopathies, thyroid dysfunctions, autoimmune diseases, epilepsy, depression, severe neutropenia and thrombocytopenia), active usage of narcotics and alcohol, pregnancy. The study protocol was designed in conformance with the Declaration of Helsinki ethical guidelines and was approved by the Ethical Committee of Belgrade School of Medicine.

The degree of fibrosis was assessed at baseline, using both non-invasive (FibroScan, Echosens, Paris, France) and invasive diagnostic methods (aspiration liver biopsy, Institute for pathology, Belgrade School of Medicine), and METAVIR score was used to mark necroinflammatory activity of the liver. Viral loads were measured with quantitative PCR HCV RNA (Cobas Amplicor HCV Test version 2.0, Roche Diagnostics, Mannheim, detection: $50 \mathrm{lU} / \mathrm{mL}$ ) and hepatitis $\mathrm{C}$ virus genotype detected (Linear Array HCV genotyping test, Roche Diagnostics) in Virology laboratory, Microbiology Department, Clinical Center of Serbia. Biochemical analysis of blood samples from the study group was performed using Siemens Dimension Xpand $\AA$ biochemistry analyzer in the Centre for Medical Biochemistry, Department of the Clinic for Infectious and Tropical Diseases, Clinical Centre of Serbia. However biochemical data was not available in healthy control group due to confidentiality.

Control group included healthy 42 blood donors. Informed written consent for the molecular analyses was obtained from each participant. Control group was matched for gender with a study group. A $5 \mathrm{ml} \mathrm{Na}$-citrate tube of whole blood was obtained for each subject. All analyzed subjects were of Serbian origin. Molecular genetic analysis was performed at the Institute of Molecular Genetics and Genetic Engineering, University of Belgrade.

DNA was extracted from blood samples using the QIAamp ${ }^{\circledR}$ DNA Blood Mini Kit (Qiagen, Hilden, Germany). The number of TA repeats in UGT1A1 promoter was genotyped as previously described with slight modifications (19). The amplification reaction was performed in a total volume of $25 \mu \mathrm{L}$, and the reaction mix contained 20 pmol of each primer, $50-100 \mathrm{ng}$ of genomic DNA, $200 \mu \mathrm{mol} / \mathrm{L}$ of each dNTP (Fermentas, ON, Canada), $1 \times \mathrm{PCR}$ reaction buffer (Qiagen), $1 \times \mathrm{Q}$ solution (Qiagen), $2.75 \mathrm{mmol} / \mathrm{L} \mathrm{MgCl} 2,1 \mathrm{U}$ HotStar DNA polymerase (Qiagen). The temperature profile of the PCR reactions was for the initial activation of DNA polymerase set at $95{ }^{\circ} \mathrm{C}$ for $15 \mathrm{~min}$, followed by 35 cycles of $30 \mathrm{sec}$ denaturation at $95{ }^{\circ} \mathrm{C}, 30 \mathrm{sec}$ annealing at $63{ }^{\circ} \mathrm{C}$, and $30 \mathrm{sec}$ elongation at $72{ }^{\circ} \mathrm{C}$, ended by a final extension period of $7 \mathrm{~min}$ at $72{ }^{\circ} \mathrm{C}$. PCR fragments were visualized on $2 \%$ agarose gel and finally analyzed using 15\% acrylamide electrophoresis (19:1 acrylamide/bisacrylamide in $1 \times \mathrm{TBE}$ buffer, run at $300 \mathrm{~V}$ and $60 \mathrm{~mA}$ for $5 \mathrm{~h}$ ) stained with Ag-nitrate (20).

Statistical analysis was performed using Statistical Package for Social Sciences (SPSS ${ }$, version 11.5) and included both descriptive and analytical methods. Subjects were grouped and categorized according to the presence of three different genotypes (6/6 wild type, 6/7 heterozygote, $7 / 7$ homozygote), depending on the number of TA repeats in the promoter region of UGT1A1 gene. Both parametric (Student's test) and nonparametric tests ( $\chi^{2}$, Kruskal Wallis, Fisher's exact test) were used, depending on the normality of variables. Linear regression and beta coefficient were also computed for the analysis of association. Values at the p 0.05 level were consid- 
ered statistically significant, the confidence interval (Cl) was $95 \%$ and all performed tests were 2 -tailed.

\section{Results}

\section{Pretreatment and healthy blood donors}

A total of 84 subjects were categorized in two groups- study group of 42 patients with $\mathrm{CHC}$ and control group of 42 healthy blood donors. In both groups, all subjects were Caucasians of similar ancestry and ethnicity (Serbian), with no significant differences in sex distribution (Table I). In the study group there were 24 (57.1\%) male and 18 (42.9\%) female, similar to healthy control group- 25 male (59.5\%) and 17 $(40.5 \%)$ female $(p=0.825)$. However, there were significant differences regarding age, as the patients' group included older subjects (mean age 46.2 \pm 9 years) compared to the control group (33.9 \pm 14 years) with younger healthy subjects $(p<0.001)$.

Frequencies of UGT1A1 TA promoter genotypes are presented in Table $/$ and $7 / 7$ genotype was observed in 10 (23.8\%) patients and 7 (16.7\%) healthy controls, but there were no significant differences in genotype frequencies between the study group and healthy control group $(p=0.49)$.

Further analysis of (pretreatment) characteristics of patients with $\mathrm{CHC}$, including hepatitis $\mathrm{C}$ genotypes, viremia and the degree of fibrosis (METAVIR score), did not reveal any statistically significant differences in two patients' groups depending on the finding of UGT1A1*28 genotype (Table II).

Patients with UGT1A1*28 genotype had higher average values of total bilirubin $(p=0.001)$ and lower values of ferritin $(p=0.032)$, but there were no other significant differences in average values of other liver function tests: alanine aminotransferase (ALT), aspartate aminotransferase (AST), gamma-glutamyl

Table I Demographic data and UGT1A1 genotype frequencies in patients with chronic hepatitis $C(n=42)$ and healthy control group $(n=42)$.

\begin{tabular}{|l|c|c|c|}
\hline Variables & $\begin{array}{c}\mathrm{CHC}^{1} \\
\text { patients } \\
(\mathrm{n}=42)\end{array}$ & $\begin{array}{c}\text { Healthy } \\
\text { control } \\
(\mathrm{n}=42)\end{array}$ & p-value \\
\hline Sex, $\mathrm{n}(\%)$ & $18(42.9 \%)$ & $17(40.5 \%)$ & 0.825 \\
\hline Female & $24(57.1 \%)$ & $25(59.5 \%)$ & \\
\hline Male & $46.2 \pm 9$ & $33.9 \pm 14$ & $<0.001$ \\
\hline $\begin{array}{l}\text { Age, years } \\
\text { (mean } \pm \text { SD) }\end{array}$ & & & \\
\hline Genotype, $\mathrm{n}(\%)$ & $18(42.9 \%)$ & $15(35.7 \%)$ & 0.49 \\
\hline wild-type 6/6 & $14(33.3 \%)$ & $20(47.6 \%)$ & \\
\hline heterozygote $6 / 7$ & $10(23.8 \%)$ & $7(16.7 \%)$ & \\
\hline homozygote $7 / 7^{2}$ & 10 & \\
\hline
\end{tabular}

${ }^{1} \mathrm{CHC}$-chronic hepatitis $\mathrm{C}$

${ }^{2}$ UGT1A1*28-Gilbert Syndrome
Table II Baseline (pretreatment) characteristics of $\mathrm{CHC}$ patients $(n=42)$ grouped according to the presence of UGT1A1*28 genotype and association with hepatitis $C$ virus genotypes, viremia the degree of fibrosis.

\begin{tabular}{|l|c|c|c|}
\hline Variables & $\begin{array}{c}\text { homozygote } \\
7 / 7^{1}(\mathrm{n}=10)\end{array}$ & $\begin{array}{c}\text { wild-type and } \\
\text { heterozygote } \\
(\mathrm{n}=32)\end{array}$ & p-value \\
\hline $\mathrm{HCV}^{3}$ genotype, $\mathrm{n}(\%)$ & $62(68.8 \%)$ & 0.856 \\
\hline G1 & $6(60 \%)$ & $2(6.3 \%)$ & \\
\hline G2 & $1(10 \%)$ & $8(25 \%)$ & \\
\hline G3 & $3(30 \%)$ & & \\
\hline HCV viral load (IU/mL) & $3(30 \%)$ & $11(34.4 \%)$ & 0.798 \\
\hline$<800.000$ & $7(70 \%)$ & $21(65.6 \%)$ & \\
\hline$>800.000$ & $5(50 \%)$ & $13(40.6 \%)$ & 0.501 \\
\hline fibrosis stage4, n (\%) & $9(28.1 \%)$ & \\
\hline F2 & $1(10 \%)$ & $10(31.3 \%)$ & \\
\hline F3 & $4(40 \%)$ &
\end{tabular}

${ }^{1}$ UGT1A1*28-Gilbert syndrome

${ }^{2}$ wild type $6 / 6$, heterozygote $6 / 7$

${ }^{3} \mathrm{HCV}$-hepatitis $\mathrm{C}$ virus

${ }^{4}$ METAVIR score: F2 - portal fibrosis with few septa;

F3 - numerous septa without cirrhosis; F4 - cirrhosis

Table III Pretreatment mean values of relevant biochemical markers in patients with $\mathrm{CHC}$ grouped according to the presence of UGT1A1*28 genotype.

\begin{tabular}{|l|c|c|c|}
\hline $\begin{array}{l}\text { Biochemical } \\
\text { markers } \\
(\text { mean } \pm S D)\end{array}$ & $\begin{array}{c}\text { homozygote } \\
7 / 7^{1} \\
(n=10)\end{array}$ & $\begin{array}{c}\text { heterozygote } \\
\text { and wild-type } \\
(n=32)\end{array}$ & p-value \\
\hline AST (U/L) & $71.5 \pm 57$ & $65.4 \pm 38.4$ & 0.703 \\
\hline ALT $(\mathrm{U} / \mathrm{L})$ & $172.7 \pm 102$ & $114.5 \pm 93$ & 0.174 \\
\hline GGT $(\mathrm{U} / \mathrm{L})$ & $58.7 \pm 69$ & $67.3 \pm 70.9$ & 0.796 \\
\hline albumin $(\mathrm{g} / \mathrm{L})$ & $38 \pm 9.3$ & $40 \pm 7.72$ & 0.339 \\
\hline $\begin{array}{l}\text { total proteins } \\
(\mathrm{g} / \mathrm{L})\end{array}$ & $71.7 \pm 7.5$ & $72.6 \pm 9.09$ & 0.598 \\
\hline ferritin $(\mu \mathrm{g} / \mathrm{mL})$ & $66.1 \pm 63.2$ & $184.09 \pm 163.3$ & 0.032 \\
\hline $\begin{array}{l}\text { total bilirubin } \\
(\mu \mathrm{mol} / \mathrm{L})\end{array}$ & $19.5 \pm 7$ & $10.98 \pm 5.2$ & 0.001 \\
\hline
\end{tabular}

${ }^{1}$ UGT1A1*28-Gilbert syndrome

2 wild type $6 / 6$, heterozygote $6 / 7$

transferase (GGT), total protein and albumin (Table III). In-depth analysis of total bilirubin levels revealed that $6(60 \%)$ of patients with UGT1A1*28 genotype had hyperbilirubinemia above $17 \mu \mathrm{mol} / \mathrm{L}$ compared to only $2(6.3 \%)$ of patients who did not have homozygous $7 / 7$ genotype $(p=0.001)$. Regression analysis of biochemical markers revealed a statistically significant association of ferritin $(\beta=0.462, p=0.002)$ and bilirubin levels $(\beta=0.542, p=0.001)$ with the presence of UGT1A1*28 genotype. 


\section{Treatment and follow-up of patients}

After initial phase and during the antiviral treatment, none of the patients had severe ribavirin-related hemolysis and/or severe indirect hyperbilirubinemia, independently of the presence of UGT1A1*28 genotype. However, 19 (45.2\%) of patients had temporarily received reduced doses of interferon and 9 (21.4\%) of ribavirin. Two patients $(4.7 \%)$ had a temporary interruption of treatment, due to severe depression and endocrine abnormalities. These dose reductions and treatment interruptions were not related to the presence of UGT1A1*28 genotype ( $p>0.05)$ and did not affect treatment success, as all patients achieved SVR.

The follow-up period of patients, after achieving SVR ranged from 20 months to 11,3 years (mean was $66.9 \pm 37$ months). Among the patients who responded to our invitation for reevaluation 14 $(33.3 \%)$ had detectable viremia, and were considered late relapsers. There was no statistically significant correlation between the occurrence of relapse and presence of UGT1A1*28 genotype ( $p=0.638)$. Eleven patients $(26.2 \%)$ had progression of fibrosis verified by fibroscan, and 3 patients in this group had also a virological relapse (27.2\%). There was a statistically significant correlation between levels of AST, ALT, GGT and detectable viremia with fibrosis progression $(p<0.05)$.

In patients with late virological relapse mean ALT values were higher (Table IV) compared to patients with stabile SVR $(p=0.004)$ however, there was no statistically significant difference in platelet counts, or other biochemical markers such as AST, GGT, alpha-phetoprotein (AFP) or total bilirubin levels. During follow up period two patients developed decompensation of cirrhosis-with ascites, and one of them a concomitant surgically-resected hepatocellular carcinoma $(\mathrm{HCC})$.

Table IV Relevant laboratory markers including biochemical, haematological and tumor markers in patients grouped according to the presence of detectable hepatitis $C$ viremia in spite of achieving SVR.

\begin{tabular}{|l|c|c|c|}
\hline $\begin{array}{l}\text { Laboratory markers } \\
(\text { mean } \pm S D)\end{array}$ & $\begin{array}{c}\text { late relapse } \\
(\mathrm{n}=14)\end{array}$ & $\begin{array}{c}\text { stabile SVR } \\
(\mathrm{n}=28)\end{array}$ & $\mathrm{p}$-value \\
\hline AST $(\mathrm{U} / \mathrm{L})$ & $43.1 \pm 32$ & $27.7 \pm 20.1$ & 0.076 \\
\hline ALT $(\mathrm{U} / \mathrm{L})$ & $50.3 \pm 39.6$ & $28.3 \pm 21.1$ & 0.004 \\
\hline GGT $(\mathrm{U} / \mathrm{L})$ & $38.4 \pm 47.7$ & $42.5 \pm 20.2$ & 0.754 \\
\hline $\begin{array}{l}\text { total bilirubin } \\
(\mu \mathrm{mol} / \mathrm{L})\end{array}$ & $8.7 \pm 5.4$ & $7.6 \pm 5.1$ & 0.51 \\
\hline AFP $(\mathrm{ng} / \mathrm{mL})$ & $10.1 \pm 7.1$ & $5.1 \pm 3.3$ & 0.06 \\
\hline Platelets $\left(\times 10^{9} / \mathrm{L}\right)$ & $196 \pm 42.1$ & $190 \pm 80$ & 0.796 \\
\hline
\end{tabular}

${ }^{1}$ SVR-sustained virological responce

${ }^{2}$ AFP-Alpha-fetoprotein

\section{Discussion}

Gilbert syndrome is the most common genetic cause of hyperbilirubinemia, present worldwide in all ethnicites, with variable frequencies $(21,22)$. The cause of GS is UGT1A1*28 genetic variant, which is also associated with abnormalities of hepatobiliary transport and additional linked variants (in $94 \%$ of GS) UGT1A $6^{*} 2$ and UGT1A7*3, resulting in reduction in enzyme UGT1A1 activity (23). So far in Serbia there has been no available data concerning the role of this genetic variant in any hepatic disease, especially in patients with severe liver damage. Our study group included patients with $\mathrm{CHC}$ with significant liver fibrosis (33\% of patients had cirrhosis), as this particular group of patients is of the utmost interest in everyday clinical practice. They present a formidable therapeutic challenge with lower antiviral treatment success rates, higher risk for complications, HCC, loss of work productivity and reduction in health related quality of life (24). Our local success rates of antiviral treatment with pegylated interferon and ribavirin are among the higher- on average $79.7 \%$ of patients achieved end of treatment response (EOT) and 70.5\% sustained virological response (SVR). This is probably due to younger age of patients, shorter duration of HCV infection, treatment naiveness, good compliance and antiviral drug dose adjustments $(25,26)$. Published data in Serbian patients show that older age-above 40 years, genotype $1 \mathrm{~b}$ and presence of cirrhosis are negative predictors of SVR, similar to the results of other European investigators $(15,27,28)$.

The frequency of UGT1A1*28 genotype in this study was high in both groups- patients with $\mathrm{CHC}$ $23.8 \%$ and healthy blood donors $16.7 \%$. These frequencies are among the highest of the published data in blood donors ranging from $5 \%$ in lceland, $10 \%$ in Portugal, 11.6\% in Spain, 15.3\% in Croatia and especially compared to Southeast Asia, Melanesia, and the Pacific Islands, ranging from 0 to $5 \%(5,13,29)$. The recognized prevalence is probably much lower than the real frequencies of the mutations, making GS underdiagnosed, due to incomplete penetrance and other acquired or inherited conditions affecting bilirubin metabolism, which can also alter clinical manifestation (30). One of the specificities of our study population is its genetic homogeneity and similar ethnic background, which might account for differences compared to published data.

So far there have been very few studies analyzing UGT1A1 promoter genotypes frequencies in patients with $\mathrm{CHC}$. Urbanek $\mathrm{P}$ et al. (31) reported frequency of this genetic variant in $15.7 \%$ of patients with CHC, Souza et al. (5) $10.4 \%$ in a larger-scale patient study. However both of these studies had multiethnic populations with very different genetic background.

Some studies have reported gender differences, especially in serum bilirubin levels, which are proba- 
bly the result of hormonally induced discordance in bilirubin clearance (32). They do not appear to be caused by gender specific differences in the UGT1A1*28 genotype frequencies (33). There is some data pointing to an association with age, body mass, ethanol consumption, smoking or oral contraceptive use $(34,35)$. However in our study there were no statistically significant gender differences in UGT1A1*28 genotype frequencies in both study and control groups, but we observed that the healthy blood donors were younger than study group. This difference in age has no effect on results, as genetic variants are inherited and not related to age.

Our analysis did not reveal significant relationship between presence of UGT1A $1 * 28$ genotype and hepatitis $C$ virus related markers- baseline viral load or genotype, as well as associations with baseline liver histology and the degree of fibrosis related, similar to published data (31). This is probably due to the fact that liver fibrosis in chronic hepatitis $C$ is multicausal, including genetically determined factors as well as oxidative stress, immune cell injury and apoptosis. Numerous factors that may explain the lack of association between degree of liver injury and examined UGT1A1 genetic variants, such as the age of onset of hepatitis $C$ infection and the duration of infection as well as insulin resistance, body mass index or environmental factors (36).

After pretreatment analysis of liver function tests and biochemical markers commonly used for diagnostic orientation in patients with $\mathrm{CHC}$, we found significant associations of the bilirubin and ferritin levels with UGT1A1*28 genotype, similar to results by Piekuse L. et al. (37) and de Souza et al. (5). Hyperbilirubinemia caused by reduced UGT1A1 activity in patients with hepatitis $\mathrm{C}$ has been documented in reports of severe ribavirin-induced jaundice, after commencing pegylated interferon and ribavirin therapy, suggesting usefulness of genotyping for UGT1A1*28 variant for the decision to continue therapy with ribavirin (38). Elevated bilirubin due to UGT1A1*28 variant can be a cause for exclusion of patients from clinical trials, as well as overestimation of liver disease prognostic scores (Child-Pugh and Model for End Stage Liver Disease-MELD) $(39,40)$. Bilirubin levels have also been observed to correlate with the total number of TA repeats $(2,5)$. The observed association of UGT $1 A 1^{*} 28$ allele with serum ferritin levels has been previously documented in few studies which included patients with $\mathrm{CHC}$ (37). Serum iron markers (ferritin and transferrin) are suggested as surrogate markers for liver fibrosis and necroinflammatory activity. Higher levels of ferritin have been linked to more severe liver inflammation, fibrosis and therefore lower response antiviral treatment rates $(41,42)$. According to our findings UGT1A1*28 genotype was associated with lower ferritin levels, and although we found no association with degree of liver fibrosis, this may point to a group of patients with a better antiviral treatment response. However no statistically significant differences in mean values of liver function tests- transaminase levels, GGT, total proteins and albumin, or their associations with the presence of UGT1A1*28 genotype were observed.

Multiple well studied pharmacogenetic risks associated with UGT1A $1 * 28$ presence may prompt for different treatment options (6-10). In our study group, during antiviral treatment with pegylated interferon and ribavirin, we observed no episodes of severe hemolysis or high indirect hyperbilirubinemia, independent of the presence of UGT1A1*28 genotype. However there have been published reports of individual cases of significant elevation of indirect bilirubin in patients with UGT1A1*28 genotype during the initial phase of combined antiviral therapy, prompting for temporary ribavirin dose reduction, but without deterioration in liver function or effect on treatment outcome (43).

Although survival and complications are much improved in patients with successful treatment, there has been overwhelming evidence that in spite of achieving SVR, liver injury can persist and progress. As our patients had a severe baseline liver damage and were involved in a long term follow-up, we were particularly interested in host genetics factors influencing the clinical course and durability of SVR in relation to presence of UGT1A1*28 genotype. Published data show that SVR appears durable in the majority of patients at 5 years post- treatment, driven mostly by an increased reinfection risk, with 5 -year recurrence rates of $0.95 \%, 10.67 \%$, and $15.02 \%$ in the low-risk, high-risk, and coinfection groups, respectively (44). There are no published data or involvement in any European monitoring systems of $\mathrm{HCV}$ infection in Serbia, as well as no long- term follow- up studies, except our clinical observations and patients feedback during a decade of regular check ups. Due to a selection bias and the fact that the patients who already knew of relapse were highly motivated to be reevaluated, the number of patients with late relapse in our study was exceptionally high we found detectable viremia in 5 new patients and had reconfirmed in 9 that were already known. However we did not observe statistically significant association between the presence of UGT1A1*28 genotype and occurrence of relapse. As it is an inherited trait, the analysis would not be affected by selection bias, and although we found no significant correlation, these are the first results on this subject.

As this was a pilot study, main study limitations are the small sample size and the lack of data concerning biochemical tests in healthy control group. However the conclusions are similar to other authors with much larger samples, including the frequency of UGT $1 A 1^{*} 28$ genotype, which is more geographically and ethnically specific for this study population and our region. 
In the group of patients with late relapse, we had a response-bias, as most of the patients from this group had previously been evaluated and aware of relapse, so they were especially motivated to respond to our invitation for reevaluation. However, we were not able to exclude reinfection by RNA sequencing, except by retesting virus genotypes. Nevertheless, in this group we had no previous or active intravenous drug users, and the dominant mode of hepatitis $C$ virus infection was through blood transfusion. We used non-invasive methods such as fibroscan and ultrasonography to monitor patients for progress of fibrosis and liver-related complications, as repeated liver biopsies are not ethically justified.

\section{References}

1. Strassburg CP. Pharmacogenetics of Gilbert's syndrome. Pharmacogenomics 2008; 9(6): 703-15.

2. Lin JP, Vitek L, Schwertner HA. Serum bilirubin and genes controlling bilirubin concentrations as biomarkers for cardiovascular disease. Clin Chem 2010; 56(10): 1535-43.

3. Franchini M, Targher G, Lippi G. Serum bilirubin levels and cardiovascular disease risk: a Janus Bifrons? Adv Clin Chem 2010; 50: 47-63.

4. Radlović N. Hereditary hyperbilirubinemias. Srp Arh Celok Lek 2014; 142(3-4): 257-60.

5. De Souza M, Vaisberg $V$, Abreu $R$, Ferreira $A$, da SilvaFerreira C, Nasser $P$, et al. UGT1A1*28 relationship with abnormal total bilirubin levels in chronic hepatitis $C$ patients: Outcomes from a case-control study. Medicine (Baltimore) 2017; 96(11): e6306.

6. Innocenti F, Undevia SD, lyer L, et al. Genetic variants in the UDP-glucuronosyltransferase 1A1 gene predict the risk of severe neutropenia of irinotecan. J Clin Oncol 2004; 22: 1382-8.

7. Shibata T, Minami Y, Mitsuma A, Morita S, Inada-Inoue $M$, Oguri $T$, et al. Association between severe toxicity of nilotinib and UGT1A1 polymorphisms in Japanese patients with chronic myelogenous leukemia. Int J Clin Oncol 2014; 19(2): 391-6.

8. Wang LZ, Ramírez J, Yeo W, Chan MY, Thuya WL, Lau $J Y$, et al. Glucuronidation by UGT1A1 is the dominant pathway of the metabolic disposition of belinostat in liver cancer patients. PLoS One 2013; 8(1): e54522.

9. Culley CL, Kiang TK, Gilchrist SE, Ensom MH. Effect of the UGT1A $1 * 28$ allele on unconjugated hyperbilirubinemia in HIV-positive patients receiving Atazanavir: a systematic review. Ann Pharmacother 2013; 47(4): 561-72.

10. Park WB, Choe PG, Song KH, Jeon JH, Park SW, Kim HB, et al. Genetic factors influencing severe atazanavir-associated hyperbilirubinemia in a population with low UDPglucuronosyltransferase $1 \mathrm{~A} 1 * 28$ allele frequency. Clin Infect Dis 2010; 51(1): 101-6.
Further investigation is needed on host-related genetic factors and on more patients with hepatitis $C$, especially in the light of new treatment options that might be available in our country for patients with severe liver damage and hepatitis $C$ relapse.

Acknowledgements. This work was supported by Ministry of Education, Science and Technological Development, Republic of Serbia (Grant No. III41004).

\section{Conflict of interest statement}

The author stated that she has no conflicts of interest regarding the publication of this article.

11. Pavlović S, Zukić B, Stojiljković-Petrović M. Molecular genetic markers as a basis for personalized medicine. J Med Biochem 2014; 33: 8-21.

12. Tseng CS, Tang KS, Lo HW, et al. UDP-glucuronosyltransferase $1 A 7$ genetic polymorphisms are associated with hepatocellular carcinoma risk and onset age. Am J Gastroenterol 2005; 100: 1758-63.

13. Premawardhena A, Fisher CA, Liu YT, Verma IC, de Silva $S$, Arambepola $M$, et al. The global distribution of length polymorphisms of the promoters of the glucuronosyltransferase 1 gene (UGT1A1): hematologic and evolutionary implications. Blood Cells Mol Dis 2003; 31(1): 98-101.

14. Mitrović N, Delić D, Marković-Denić L, Jovičić M, Popović N, Bojović K, et al. Seroprevalence and risk factors for hepatitis $\mathrm{C}$ virus infection among blood donors in Serbia: A multicentre study. Dig Liver Dis 2015; 47(7): 572-6.

15. Švirtlih N, Delić D, Simonović J, Jevtović D, Dokić L, Grozdenović E, et al. Hepatitis C virus genotypes in Serbia and Montenegro: the prevalence and clinical significance. World J Gastroenterol 2007; 13(3): 355-60.

16. Serfaty L. Follow-up of patients with chronic hepatitis $C$ and a sustained viral response. Liver Int 2016; 36 Suppl 1: 67-71.

17. Innes HA, Hutchinson SJ, Allen S, Bhattacharyya D, Bramley P, Delahooke TE, et al. Excess liver-related morbidity of chronic hepatitis $C$ patients, who achieve a sustained viral response, and are discharged from care. Hepatology 2011; 54(5): 1547-58.

18. Tachi Y, Hirai T, Miyata A, Ohara K, lida T, Ishizu Y, et al. Progressive fibrosis significantly correlates with hepatocellular carcinoma in patients with a sustained virological response. Hepatol Res 2015; 45(2): 238-46.

19. Lippi G, Chiozza L, Mattiuzzi C, Plebani M. Patient and sample identification. Out of the maze? J Med Biochem 2017; 36: 107-12.

20. Radojković D, Kusić J. Silver staining of denaturing gradient gel electrophoresis gels. Clin Chem 2000; 46(6 Pt 1): 883-4. 
21. Owens D, Evans J. Population studies on Gilbert's syndrome. J Med Genet 1975; 12: 152-6.

22. Beutler E, Gelbart T, Demina A. Racial variability in the UDP-glucuronosyltransferase 1 (UGT1A1) promoter: a balanced polymorphism for regulation of bilirubin metabolism. Proc Natl Acad Sci U S A 1998; 95: 8170-4.

23. Köhle C, Möhrle B, Münzel PA, Schwab M, Wernet D, Badary OA, et al. Frequent co-occurrence of the TATA box mutation associated with Gilbert's syndrome (UGT1A1*28) with other polymorphisms of the UDPglucuronosyltransferase-1 locus (UGT1A6*2 and UGT1A7*3) in Caucasians and Egyptians. Biochem Pharmacol 2003; 65(9): 1521-7.

24. Guy W. Neff, Christopher W, Eugene R. Schiff. The Current Economic Burden of Cirrhosis Gastroenterol Hepatol (N Y) 2011; 7(10): 661-71.

25. Delić D. Hronična hepatitis C virusna infekcija. In: Hronični virusni hepatitis. 1st ed. Beograd: Zavod za udžbenike, 2012: 324-5.

26. Delić D, Mitrović N, Popović N, et al. Kombinovana antivirusno-imunomodulatorna terapija - primena pegilovanog interferona alfa-2a i ribavirina kod bolesnika s hroničnim hepatitisom C. Srp Arh Celok Lek 2012; 140(9-10): 612-8.

27. Fattovich G, Ribero ML, Pantalena M, Diodati G, Almasio $P$, Nevens $F$, et al. Hepatitis $C$ virus genotypes: distribution and clinical significance in patients with cirrhosis type $C$ seen at tertiary referral centres in Europe. J Viral Hepat 2001; 8: 206-16.

28. Payan C, Roudot-Thoraval F, Marcellin P, Bled N, Duverlie $G$, Fouchard-Hubert I, et al. Changing of hepatitis $C$ virus genotype patterns in France at the beginning of the third millenium: The GEMHEP GenoCll Study. J Viral Hepat 2005; 12: 405-13.

29. Jurčić Z, Franulović O, Štefanović O. Nasljedne nekonjugirane hiperbilirubinemije. Paediatr Croat 2006; 50:112-21.

30. Hirschfield GM, Alexander GJ. Gilbert's syndrome: an overview for clinical biochemists. Ann Clin Biochem 2006; 43(Pt 5): 340-3.

31. Urbánek $P$, Leníček $M$, Muchová L, Subhanová I, Dušek L, Kasp íková N, et al. No association of promoter variations of HMOX1 and UGT1A1 genes with liver injury in chronic hepatitis C. Ann Hepatol 2011; 10(4): 445-51.

32. Manolio TA, Burke GL, Savage PJ, Jacobs DR Jr, Sidney $S$, Wagenknecht LE, et al. Sex- and race-related differences in liver-associated serum chemistry tests in young adults in the CARDIA study. Clin Chem 1992; 38(9): 1853-9.

33. Monaghan G, Ryan M, Seddon R, Hume R, Burchell B. Genetic variation in bilirubin UDP-glucuronosyltransferase gene promoter and Gilbert's syndrome. Lancet 1996: 347: 578-81.

34. Harman SM, Metter EJ, Tobin JD, Pearson J, Blackman MR. Longitudinal effects of aging on serum total and free testosterone levels in healthy men. J Clin Endocrinol Metab 2001; 86: 724-31.

35. Zucker SD, Horn PS, Sherman KE. Serum bilirubin levels in the U.S. population: gender effect and inverse correlation with colorectal cancer. Hepatology 2004; 40: 82735.

36. Mallat A, Hezode C, Lotersztajn S. Environmental factors as disease accelerators during chronic hepatitis $C$. Journal of Hepatology 2008; 48: 657-65.

37. Piekuse L, Kreile M, Zarina A, et al. Association between inherited monogenic liver disorders and chronic hepatitis C. World Journal of Hepatology 2014; 6(2): 92-7.

38. Bizya N, Sarantuya G, Namdag B. Yang S. Interferon and ribavirin combination therapy are linked to severe indirect hyperbilirubinemia in patients with nt-211G $>$ A variant of UGT1A1 gene A. Journal of the Formosan Medical Association 2015; 114: 1147-8.

39. Desmet VJ, Gerber M, Hoofnagle JH, Manns M, Scheuer PJ. Classification of chronic hepatitis: diagnosis, grading and staging. Hepatology 1994; 19: 1513-20.

40. Kamath PS, et al. A model to predict survival in patients with end-stage liver disease. Hepatology 2001; 33: 464-70.

41. Vagu C, Sultana C, Ruta S. Serum Iron Markers in Patients With Chronic Hepatitis C Infection. Hepat Mon 2013; 13(10): e13136.

42. Barut S, Günal O, Erkorkmaz U. Serum ferritin levels in chronic hepatitis $C$ patients during antiviral therapy and prediction of treatment response. Scand J Infect Dis 2012; 44(10): 761-5.

43. Deterding K, Grüngreiff K, Lankisch TO, Potthoff A, Bahr $M J$, et al. Gilbert's syndrome and antiviral therapy of hepatitis C. Ann Hepatol 2009; 8(3): 246-50.

44. Simmons B, Saleem J, Hill A, Riley RD, Cooke GS. Risk of Late Relapse or Reinfection With Hepatitis C Virus After Achieving a Sustained Virological Response: A Systematic Review and Meta-analysis. Clinical Infectious Diseases 2016; 3: 683-94. 